\title{
Douglas Fir and Ponderosa Pine Seed Dormancy as Regulated by Grassland Seedbed Conditions
}

\author{
Yuguang Bai, ${ }^{1}$ Don Thompson, ${ }^{2}$ and Klaas Broersma ${ }^{3}$
}

\begin{abstract}
Authors are ${ }^{1}$ Assistant Professor, Department of Plant Sciences, University of Saskatchewan, Saskatoon, SK S7N 5A8, Canada; and ${ }^{2}$ Range Plant Physiologist and ${ }^{3}$ Soil Scientist, Kamloops Range Research Unit, Agriculture and Agri-Food Canada, Kamloops, BC V2B 8A9, Canada.
\end{abstract}

\begin{abstract}
Tree encroachment in the ecotone between grassland and forest of interior British Columbia has resulted in decreasing grazing potential of rangelands. The 2 dominant tree species in this region, Douglas fir (Pseudotsuga menziesii var. glauca) and ponderosa pine (Pinus ponderosa), require stratification for seed dormancy release. The objective of this study was to determine whether seeds of these species can be stratified and dormancy released under grassland conditions. Field stratification experiments were conducted over 4 years using 2 Douglas fir and 3 ponderosa pine seed collections. A laboratory experiment was conducted to determine the effect of seedcoat removal, light, and stratification duration on dormancy release. Dormancy in Douglas fir and ponderosa pine was released after 1 to 2 months of stratification under grassland seedbed conditions when seeds were placed in the field in late fall and early winter. Continuous stratification until the following May was correlated with higher germination rate. One week of stratification in the laboratory was sufficient to break dormancy in the 2 species and a similar effect can be achieved by exposure to light. Seed coat removal for ponderosa pine also released dormancy, indicating that this structure imposes dormancy. Therefore, the grassland seedbeds near the forest edge can provide suitable conditions to break dormancy of Douglas fir and ponderosa pine seeds, contributing to tree encroachment into adjacent grasslands. Managements aiming to control tree encroachment should take the interaction between tree seed and grassland seedbed conditions into consideration, and the control should be focused on the elimination of seeds and seedlings but not on the germination stage.
\end{abstract}

\section{Resumen}

La invasión de árboles en el ecotono entre el zacatal y el bosque del interior de Columbia Britanica ha resultado en una disminución del potencial de apacentamiento de los pastizales. Las 2 especies dominantes de árboles en esta región, "Douglas-fir" (Pseudotsuga menziesii var. glauca) y "Ponderosa pine" (Pinus ponderosa), requieren de escarificación para romper la dormancia de la semilla. El objetivo de este estudio fue determinar si las semillas de estas especies pueden ser escarificadas y si la dormancia se rompe bajo las condiciones del pastizal. Durante 4 años se condujeron experimentos de escarificación en campo utilizando 2 colecciones de semillas de "Douglas-fir" y 3 de "Ponderosa pine". Se condujo un experimento en el laboratorio para determinar el efecto de la remoción de la cubierta de la semilla, la luz y la duración de la escarificación en la ruptura de la dormancia. Bajo las condiciones de la cama de siembra del zacatal la dormancia del "Douglas-fir" y el "Ponderosa pine" se rompió después de 1 o 2 meses de escarificada la semilla, esto cuando la semillas se colocaron en el campo a fines de otoño o inicios de invierno. La escarificación continua hasta el siguiente Mayo estuvo correlacionada con la alta tasa de germinación. Una semana de escarificación en el laboratorio fue suficiente para romper la dormancia en las dos especies y un efecto similar se puede lograr mediante la exposición a la luz. La remoción de la cubierta de la semilla del "Ponderosa pine"también liberó la dormancia, indicando que esta estructura impone dormancia. Por lo tanto, las camas de siembra de los zacatales cercanas al límite del bosque pueden proveer condiciones apropiadas para romper la dormancia de las semillas del "Douglas-fir" y "Ponderosa pine", contribuyendo a la invasión de los árboles en los zacatales adjuntos. El manejo encaminado a controlar la expansión de los árboles debe tomar en cuenta la interacción entre la semilla del árbol y las condiciones de la cama de siembra del zacatal y el control debe enfocarse a la eliminación de las semilla y las plántulas pero no en la etapa de germinación.

Key Words: Pinus ponderosa, Pseudotsuga menziesii var. glauca, tree encroachment, seed coat, seedbed ecology, light

\section{Introduction}

The dry Douglas fir (Pseudotsuga menziesii var. glauca (Beissn.) Franco) and ponderosa pine (Pinus ponderosa Dougl.) forests in interior British Columbia (BC) are adjacent to the bunchgrass grasslands dominated by rough fescue (Festuca campestris

Funding for this research was provided by Beef Cattle Industry Development Fund and AAFC Matching Investment Initiative Fund.

Correspondence: Dr Yuguang Bai, Dept of Plant Sciences, University of Saskatchewan, 51 Campus Dr, Saskatoon, SK S7N 5A8, Canada. Email: yuguang.bai@usask.ca

Manuscript received 4 December 2003; manuscript accepted 1 May 2004.
Rydb.) and bluebunch wheat grass (Agropyron spicatum (Pursh) Scribn. \& Smith). Similar to other woody plantgrassland transitional zones around the world, fire suppression, human disturbance, climatic variation, topography, and interaction of these factors have resulted in the expansion of woody plants into grasslands (Burkhardt and Tisdale 1976; White 1985; Bai et al 2004). This is causing reductions in grassland areas and affecting the livestock industries by decreasing the grazing potential (Arno and Gruell 1986; Mast et al 1998). Research has been conducted to identify the ecological and physiological mechanisms for tree encroachment (trees moving into grasslands from the adjacent forests) in this region. At the landscape level, Bai et al (2004) reported that 


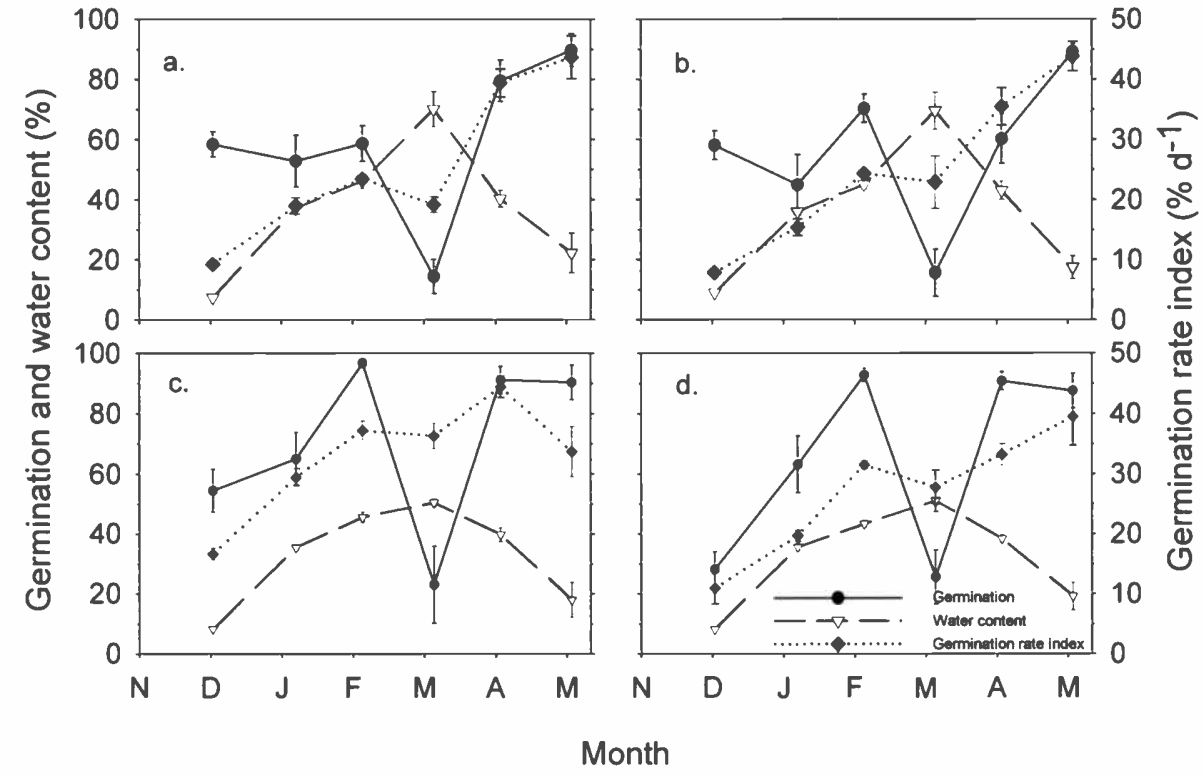

Figure 1. Seed germination, germination rate index, and seed moisture content (mean \pm SE) of 2 Douglas fir collections (a and b) and 2 ponderosa pine collections ( $\boldsymbol{C}$ and $\mathbf{d}$ ) after stratification in the field between December 1997 and May 1998. Seeds were placed in the field in December 1997, and December data were for seeds without stratification.

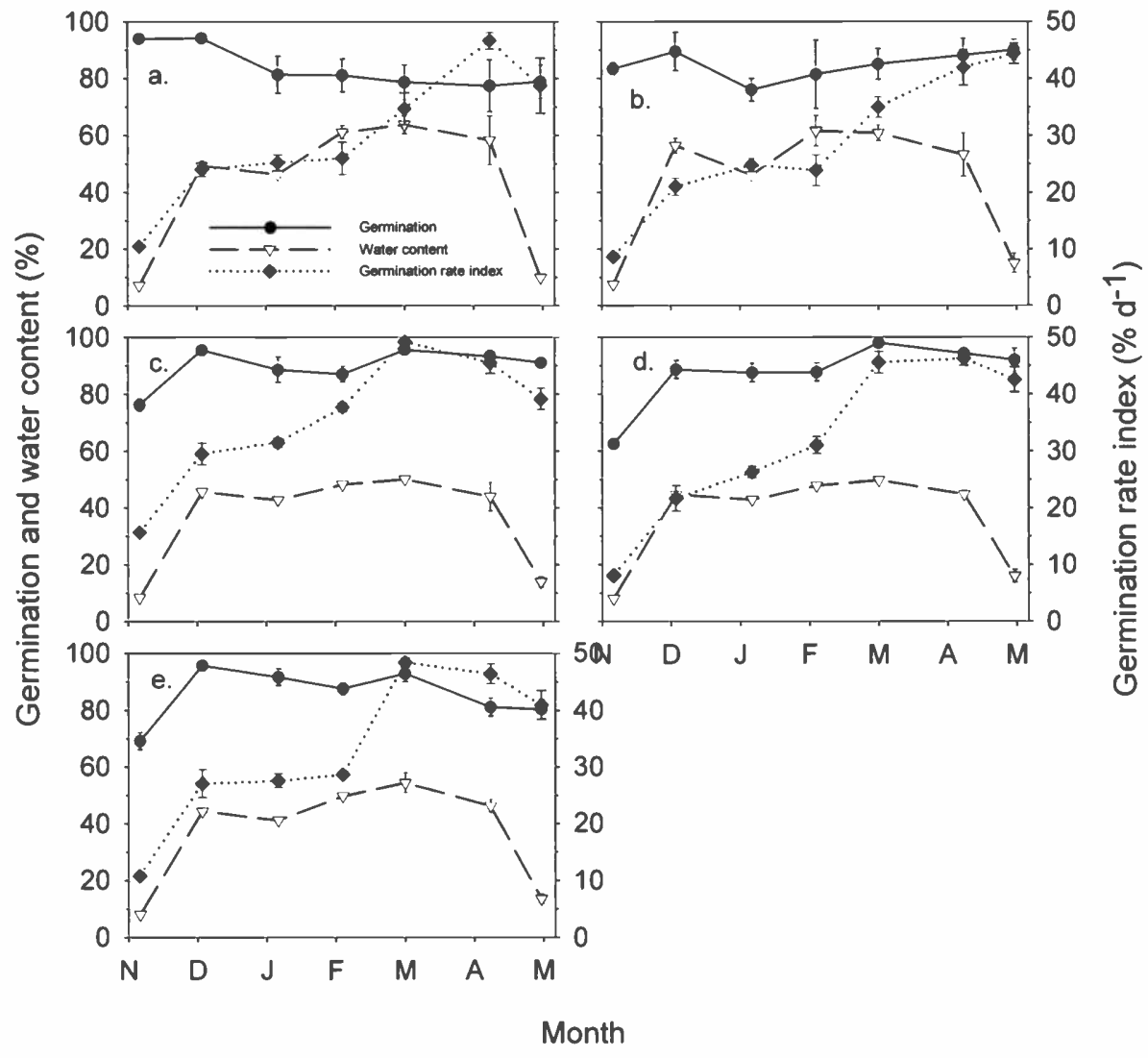

Figure 2. Seed germination, germination rate index, and seed moisture content (mean $\pm \mathrm{SE}$ ) of 2 Douglas fir collections (a and $\mathbf{b}$ ) and 3 ponderosa pine collections (c, d, and e) after stratification in the field between November 1998 and May 1999. Seeds were placed in the field in November 1998, and November data were for seeds without stratification. 


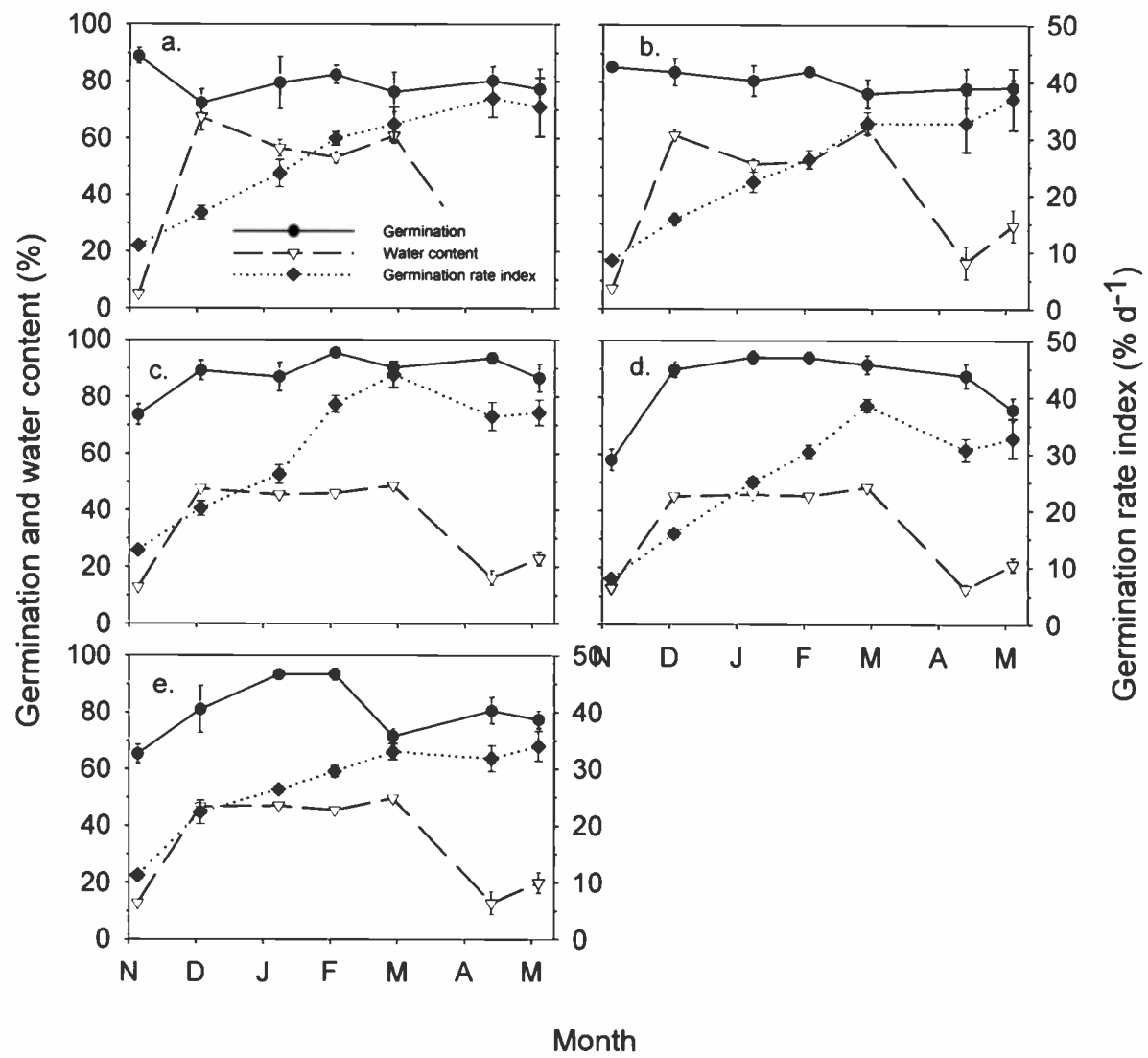

Figure 3. Seed germination, germination rate index, and seed moisture content (mean \pm SE) of 2 Douglas fir collections (a and b) and 3 ponderosa pine collections (c, d, and e) after stratification in the field between November 1999 and May 2000. Seeds were placed in the field in November 1999, and November data were for seeds without stratification.

topography has a major influence on tree encroachment and ingrowth (increasing tree density in existing forests). The probability of tree encroachment is higher on south-facing slopes even though there is a higher probability of ingrowth on northfacing slopes. The probability of tree encroachment is inversely correlated with percent slope. At the microsite level, the physical and chemical characteristics of grassland seedbeds, given sufficient moisture, actually favor germination of Douglas fir and ponderosa pine seeds over the seedbeds on the needlecovered forest floor (Bai et al 2000).

Similar to most temperate species, Douglas fir and ponderosa pine seeeds are in various degrees of dormancy at the time of dispersal, and stratification is usually required to break the dormancy (Bewley and Black 1994; Jones and Gosling 1994). Mechanisms regulating germination are under selective pressure and have adaptive value (Harper 1977). In grasslands adjacent to forests, the lack of or reduced tree cover may alter the retention, accumulation, and duration of snow cover. This may modify the thermal and moisture environment surrounding seeds and subsequently determine whether the stratification requirements are met so seeds are ready to germinate in the spring when conditions are favorable. Therefore, studies on field stratification of these species are important for understanding the ecological mechanisms of tree encroachment, but such information is limited for coniferous species. The objective of this study was to determine whether seeds of Douglas fir and ponderosa pine can be stratified and dormancy released under grassland conditions. We also examined the effectiveness of artificial treatments such as controlled stratification, light, and seed coat removal on the reduction of seed dormancy.

\section{Materials and Methods}

\section{Seed Collection}

Two collections of Douglas fir and 3 collections of ponderosa pine seeds were obtained from the BC Ministry of Forests Tree Seed Centre, Victoria, British Columbia, and a commercial source. These seeds were collected from low elevation sites ( $<1000 \mathrm{~m}$ above sea level) in the grassland/forest transitional region, within $50 \mathrm{~km}$ of Kamloops, British Columbia. Details on seed sources can be found in Bai et al (2000). Seeds were extracted from cones after fall collection following industry standard and stored at $-18^{\circ} \mathrm{C}$ until use. Seed moisture content was about $10 \%$ dry weight (dw).

\section{Experiment 1: Effect of Field Stratification on Dormancy Change}

The experiment was conducted in the Lac du Bois Grasslands near Kamloops inside a long-term exclosure at $900 \mathrm{~m}$ above sea level dominated by rough fescue. Screen cages, $40 \times 42 \times 5 \mathrm{~cm}$, were placed on the ground where live vegetation and litter had been removed. They were fixed to the ground by nails and the bottom was covered with $1-\mathrm{cm}$-depth of mineral soil to a level 


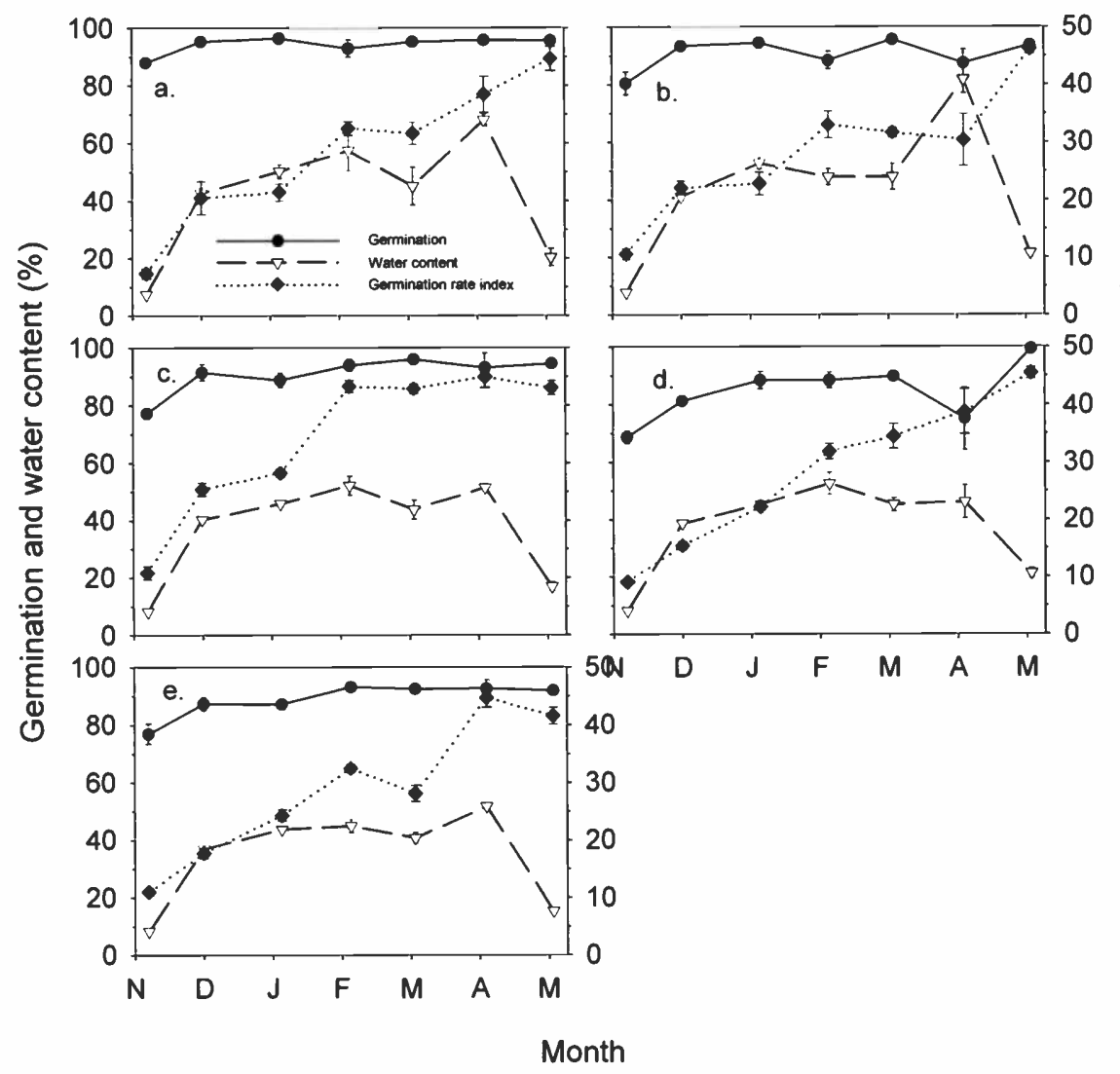

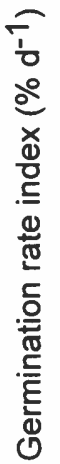

Figure 4. Seed germination, germination rate index, and seed moisture content (mean \pm SE) of 2 Douglas fir collections (a and $\mathbf{b}$ ) and 3 ponderosa pine collections (c, d, and e) after stratification in the field between November 2000 and May 2001. Seeds were placed in the field in November 2000 , and November data were for seeds without stratification.

similar to the immediate surroundings. Approximately 70 seeds were placed in a $1-\mathrm{mm}$ metal screen envelope and soaked in precooled distilled water at $4^{\circ} \mathrm{C}$ for 2 hours. Envelopes containing seeds of ponderosa pine and Douglas fir were randomly placed at the bottom of each cage and covered with a thin layer of fescue litter. The lids of cages were sealed with metal wires. One centimeter of water was uniformly applied to each cage. There were 5 replications (blocks). The experiment was initiated in early December 1997 with 2 ponderosa pine and 2 Douglas fir collections. It was repeated in early November of 1998, 1999, and 2000 using the same 4 seed collections plus a third ponderosa pine collection. Envelopes containing seeds were retrieved monthly from the field between placing date and the following May. Ten seeds from each envelope were used for seed moisture determination ( $\% \mathrm{dw}$ ) using the oven-drying method at $80^{\circ} \mathrm{C}$ for 48 hours after the removal of dirt, snow, and surface water. The remaining seeds (approximately 60 per envelope) were placed on 2 layers of Whatman \# 1 filter paper and covered with 1 layer of filter paper in a petri dish. Four milliliters of distilled water were added to each petri dish. These petri dishes were enclosed in clear plastic bags and incubated at $25^{\circ} \mathrm{C}$ with 16 hours of light/ 8 hours of darkness as recommended by Young and Young (1992). Seed germination was checked every 2 days for 4 weeks and seeds with a radicle $\geq 2 \mathrm{~mm}$ in length were considered germinated. Viability of ungerminated seeds was determined at the end of the experiment on the basis of their firmness.

\section{Experiment 2: Effect of Controlled Stratification, Light, and Seed Coat Removal on Dormancy Change}

The seed coat of ponderosa pine was manually removed. The remaining seed structure, an embryo embedded in the megagametophyte, was referred to here as a naked seed. Naked seeds with any sign of damage or scratches were discarded. Seed coat removal of Douglas fir seeds was attempted but the treatment was abandoned because of the unavoidable damage to the embryo during this process due to the rigid seed coat and small seed size of this species. Fifty seeds were placed on 2 layers of Whatman \# 1 filter paper and covered with 1 layer of filter paper in a petri dish. Twenty milliliters of distilled water were added to each petri dish. Petri dishes were sealed in black plastic bags and placed in a growth chamber at $4^{\circ} \mathrm{C}$ in darkness for 0,1 , or 3 weeks. Seed water content ( $\% \mathrm{dw})$ before and after stratification was determined using the oven-drying method. Petri dishes were drained after stratification and 3 $\mathrm{mL}$ of distilled water were then added to each petri dish. Petri dishes containing seeds were enclosed in either clear (light treatment) or dark plastic bags and incubated at $25^{\circ} \mathrm{C}$ with 16 hours of light/ 8 hours of darkness. There were 4 replicates in the experiment and the experiment was repeated. Seed germination was checked every 2 days for 4 weeks and seeds with a radicle $\geq 2 \mathrm{~mm}$ in length were considered germinated. In the dark treatment, germination was checked in safe light (3 layers of green filter). Viability of ungerminated seeds was determined at the end of the experiment on the basis of their firmness (Bai et al 1998). 
Table 1. Germination percentage (mean $\pm \mathrm{SE}$ ) of 2 seed collections of Douglas fir (DF) and 3 collections of ponderosa pine (PP) as affected by seed coat, light, and stratifications.

\begin{tabular}{lccc}
\hline & \multicolumn{3}{c}{ Stratification duration (wk) } \\
\cline { 2 - 4 } Treatment & 0 & 1 & 3 \\
\hline
\end{tabular}

\begin{tabular}{|c|c|c|c|c|}
\hline \multirow{3}{*}{ Whole seed } & & \multicolumn{3}{|c|}{ DF 1} \\
\hline & Light & $94.0 \pm 2.0 a^{1}$ & $91.0 \pm 3.2 \mathrm{a}$ & $91.4 \pm 2.6 \mathrm{a}$ \\
\hline & Darkness & $71.0 \pm 4.0 \mathrm{~b}$ & $85.0 \pm 4.5 \mathrm{a}$ & $87.0 \pm 2.1 \mathrm{a}$ \\
\hline & & \multicolumn{3}{|c|}{ DF 2} \\
\hline \multirow[t]{3}{*}{ Whole seed } & Light & $86.0 \pm 3.4 a b$ & $65.0 \pm 5.7 \mathrm{c}$ & $82.9 \pm 2.4 b$ \\
\hline & Darkness & $63.5 \pm 4.7 \mathrm{c}$ & $81.2 \pm 2.7 b$ & $88.0 \pm 3.8 \mathrm{a}$ \\
\hline & & \multicolumn{3}{|c|}{ PP 1} \\
\hline \multirow[t]{2}{*}{ Whole seed } & Light & $70.0 \pm 3.9 b$ & $57.5 \pm 5.1 \mathrm{~cd}$ & $62.4 \pm 5.8 \mathrm{bcd}$ \\
\hline & Darkness & $57.0 \pm 3.8 d$ & $68.5 \pm 4.2 \mathrm{bc}$ & $70.0 \pm 4.5 b$ \\
\hline \multirow[t]{3}{*}{ Naked seed } & Light & $90.0 \pm 1.7 \mathrm{a}$ & $11.0 \pm 2.4 \mathrm{e}$ & $9.0 \pm 2.2 \mathrm{e}$ \\
\hline & Darkness & $88.5 \pm 3.1 \mathrm{a}$ & $7.5 \pm 2.1 \mathrm{e}$ & $5.0 \pm 2.2 \mathrm{e}$ \\
\hline & & \multicolumn{3}{|c|}{ PP 2} \\
\hline \multirow[t]{2}{*}{ Whole seed } & Light & $56.2 \pm 6.1$ cde & $74.7 \pm 4.5 \mathrm{ab}$ & $75.5 \pm 3.6 \mathrm{a}$ \\
\hline & Darkness & $46.7 \pm 5.3 \mathrm{def}$ & $67.5 \pm 3.7 a b c$ & $78.0 \pm 3.1 \mathrm{a}$ \\
\hline \multirow[t]{3}{*}{ Naked seed } & Light & $71.7 \pm 6.2 \mathrm{ab}$ & $33.3 \pm 6.0 f$ & $60.0 \pm 4.8 \mathrm{bcd}$ \\
\hline & Darkness & $75.1 \pm 2.0 \mathrm{ab}$ & $40.1 \pm 5.6 \mathrm{ef}$ & $44.5 \pm 12.4 \mathrm{def}$ \\
\hline & & \multicolumn{3}{|c|}{ PP 3} \\
\hline \multirow[t]{2}{*}{ Whole seed } & Light & $53.5 \pm 4.5 b c$ & $45.5 \pm 7.9$ bcde & $57.0 \pm 6.1 \mathrm{~b}$ \\
\hline & Darkness & $38.0 \pm 5.1$ bcdef & $35.2 \pm 7.6 \mathrm{cdef}$ & $52.5 \pm 5.6 \mathrm{bcd}$ \\
\hline \multirow[t]{2}{*}{ Naked seed } & Light & $90.5 \pm 3.2 \mathrm{a}$ & $30.0 \pm 7.7 \mathrm{def}$ & $21.0 \pm 7.0 f$ \\
\hline & Darkness & $80.4 \pm 4.2 \mathrm{a}$ & $34.2 \pm 10.5 \mathrm{cde}$ & $25.5 \pm 11.0$ ef \\
\hline
\end{tabular}

${ }^{1}$ Means with the same letters within a seed collection were not significantly different at $P \leq 0.05$.

\section{Data Analysis}

Data for each seed collection were analyzed separately. Germination rate index (GRI) was calculated as the summation of percent seed germination on each counting date divided by days of incubation and multiplied by 100 (Evetts and Burnside 1972). Germination and GRI data were transformed with arcsine square root and all data were analyzed using the Proc GLM procedure with type III SS in SAS (SAS Institute 1995). Collection date was the treatment in Experiment 1. Each combination of light, stratification duration, and seed coat removal in Experiment 2 was considered a separate treatment in the analysis. Means were separated with a least significant difference test and statistical significance for all tests was assumed at $P \leq 0.05$.

\section{Results and Discussion}

\section{Field Stratification}

Seed moisture content was about $10 \%$ before stratification each year (Figs. 1-4). A moisture content between $40 \%$ and $60 \%$ was achieved after 1 month of stratification and it remained high throughout the winter. Snow cover was between $1 \mathrm{~cm}$ and $5 \mathrm{~cm}$ in December and was mostly between $40 \mathrm{~cm}$ and $50 \mathrm{~cm}$ from January to March (data not shown). Air temperature was mild, mostly between $5^{\circ} \mathrm{C}$ and $-5^{\circ} \mathrm{C}$, at the times of seed
Table 2. Viability at the end of germination test (mean $\pm \mathrm{SE}$ ) of 2 seed collections of Douglas fir (DF) and 3 collections of ponderosa pine (PP) as affected by seed coat, light, and stratifications.

\begin{tabular}{|c|c|c|c|c|}
\hline \multirow[b]{2}{*}{ Treatment } & & \multicolumn{3}{|c|}{ Stratification duration (wk) } \\
\hline & & 0 & 1 & 3 \\
\hline & & & DF 1 & \\
\hline \multirow[t]{3}{*}{ Whole seed } & Light & $98.5 \pm 0.7 a^{1}$ & $94.0 \pm 2.1 \mathrm{ab}$ & $91.9 \pm 2.3 b c$ \\
\hline & Darkness & $96.5 \pm 1.4 a b$ & $91.5 \pm 2.7 b c$ & $88.5 \pm 2.1 c$ \\
\hline & & & DF 2 & \\
\hline \multirow[t]{3}{*}{ Whole seed } & Light & $94.5 \pm 2.8 \mathrm{a}$ & $72.5 \pm 5.4 c$ & $84.4 \pm 1.8 b c$ \\
\hline & Darkness & $95.5 \pm 1.9 \mathrm{a}$ & $91.0 \pm 1.8 \mathrm{ab}$ & $89.5 \pm 3.2 \mathrm{ab}$ \\
\hline & & & PP 1 & \\
\hline \multirow[t]{2}{*}{ Whole seed } & Light & $92.5 \pm 3.0 \mathrm{ab}$ & $58.5 \pm 5.3 d$ & $63.9 \pm 6.0 \mathrm{~cd}$ \\
\hline & Darkness & $95.0 \pm 1.6 \mathrm{a}$ & $72.0 \pm 4.7 c$ & $72.5 \pm 4.4 c$ \\
\hline \multirow[t]{3}{*}{ Naked seed } & Light & $90.0 \pm 1.7 b$ & $11.0 \pm 2.4 \mathrm{e}$ & $9.0 \pm 2.2 \mathrm{e}$ \\
\hline & Darkness & $90.5 \pm 3.3 \mathrm{ab}$ & $7.5 \pm 2.1 \mathrm{e}$ & $5.0 \pm 2.2 \mathrm{e}$ \\
\hline & & & PP 2 & \\
\hline \multirow[t]{2}{*}{ Whole seed } & Light & $87.9 \pm 4.3 \mathrm{a}$ & $78.0 \pm 5.2 b$ & $78.5 \pm 4.3 b$ \\
\hline & Darkness & $86.1 \pm 3.9 \mathrm{ab}$ & $78.5 \pm 3.9 \mathrm{~b}$ & $83.5 \pm 2.4 \mathrm{ab}$ \\
\hline \multirow[t]{3}{*}{ Naked seed } & Light & $73.2 \pm 5.6 \mathrm{bc}$ & $33.3 \pm 6.0 \mathrm{e}$ & $60.0 \pm 4.8 \mathrm{~cd}$ \\
\hline & Darkness & $75.1 \pm 2.0 \mathrm{bc}$ & $40.1 \pm 5.6 \mathrm{e}$ & $44.5 \pm 12.4 \mathrm{de}$ \\
\hline & & & PP 3 & \\
\hline \multirow[t]{2}{*}{ Whole seed } & Light & $71.0 \pm 5.7 \mathrm{bc}$ & $47.0 \pm 7.9$ defg & $57.0 \pm 6.1 \mathrm{cde}$ \\
\hline & Darkness & $63.5 \pm 6.9 \mathrm{~cd}$ & $41.6 \pm 9.2 \mathrm{efgh}$ & $52.5 \pm 5.6 \mathrm{cdef}$ \\
\hline \multirow[t]{2}{*}{ Naked seed } & Light & $90.5 \pm 3.2 \mathrm{a}$ & $30.0 \pm 7.7 \mathrm{fgh}$ & $21.0 \pm 7.0 \mathrm{~h}$ \\
\hline & Darkness & $80.4 \pm 4.2 a b$ & $34.2 \pm 10.5$ efgh & $25.5 \pm 11.0 \mathrm{gh}$ \\
\hline
\end{tabular}

${ }^{1} M e a n s$ with the same letters within a seed collection were not significantly different at $P \leq 0.05$.

retrieval between December and March. Therefore, partial snow melting and subsequent freezing may have occurred during the winter, allowing stratification to proceed. An extremely warm February followed by freezing was experienced in the 1997-1998 experiment, resulting in an increase in seed moisture content.

Germination percentage at the beginning of the 1997 experiment was between $55 \%$ and $60 \%$ for Douglas fir and between $25 \%$ and $55 \%$ for ponderosa pine (Fig. 1). These values are within the range previously reported (eg, Douglas fir, Edwards and El-Kassaby 1995). The initial germination percentage increased gradually from 1997 to 2000 to around $90 \%$ for Douglas fir and to between $70 \%$ and $80 \%$ for ponderosa pine (Figs. 1-4). Changes in initial germination each year indicate that dormancy was released slowly during storage at $-18^{\circ} \mathrm{C}$ over the 4-year period. The release of dormancy during low temperature storage has not been reported before and the mechanism is unknown. Germination percentage increased with the duration of field stratification in 1997-1998 (Fig. 1) and usually 1 month of field stratification permitted maximum germination percentage (Figs. 2-4). The level of dormancy at the beginning of the experiments varied among species and collections as indicated by the variable germination percentage from $30 \%$ to $95 \%$ (Figs. 1-4). In most cases, field stratification of 1 to 2 months enhanced seed germination to over $90 \%$. Even though dormancy was generally released after 1 or 2 months of 
Table 3. Days to $50 \%$ germination (mean $\pm \mathrm{SE}$ ) of 2 seed collections of Douglas fir (DF) and 3 collections of ponderosa pine (PP) as affected by seed coat, light, and stratifications.

\begin{tabular}{|c|c|c|c|c|}
\hline \multirow[b]{2}{*}{ Treatment } & & \multicolumn{3}{|c|}{ Stratification duration (wk) } \\
\hline & & 0 & 1 & 3 \\
\hline & & \multicolumn{3}{|c|}{ DF 1} \\
\hline \multirow[t]{3}{*}{ Whole seed } & Light & $9.8 \pm 0.5 b c^{1}$ & $8.8 \pm 0.4 \mathrm{~cd}$ & $7.5 \pm 0.3 \mathrm{e}$ \\
\hline & Darkness & $15.3 \pm 0.5 \mathrm{a}$ & $11.3 \pm 0.4 b$ & $8.5 \pm 0.5 \mathrm{de}$ \\
\hline & & \multicolumn{3}{|c|}{ DF 2} \\
\hline \multirow[t]{3}{*}{ Whole seed } & Light & $13.5 \pm 0.5 b$ & $10.8 \pm 0.5 c$ & $7.0 \pm 0.5 \mathrm{e}$ \\
\hline & Darkness & $17.5 \pm 0.7 \mathrm{a}$ & $13.5 \pm 0.5 b$ & $9.3 \pm 0.5 d$ \\
\hline & & \multicolumn{3}{|c|}{ PP 1} \\
\hline \multirow[t]{2}{*}{ Whole seed } & Light & $5.3 \pm 0.5 \mathrm{c}$ & $8.5 \pm 0.8 b$ & $8.8 \pm 0.6 b$ \\
\hline & Darkness & $14.3 \pm 0.8 \mathrm{a}$ & $12.0 \pm 1.1 \mathrm{ab}$ & $9.8 \pm 1.0 \mathrm{ab}$ \\
\hline \multirow[t]{3}{*}{ Naked seed } & Light & $3.8 \pm 0.3 d$ & $2.0 \pm 0.0 \mathrm{e}$ & $3.0 \pm 1.0 \mathrm{e}$ \\
\hline & Darkness & $3.8 \pm 0.3 d$ & - & - \\
\hline & & \multicolumn{3}{|c|}{ PP 2} \\
\hline \multirow[t]{2}{*}{ Whole seed } & Light & $16.3 \pm 1.2 \mathrm{a}$ & $9.8 \pm 1.0 \mathrm{~b}$ & $9.0 \pm 0.8 \mathrm{~b}$ \\
\hline & Darkness & $19.3 \pm 1.3 \mathrm{a}$ & $12.8 \pm 1.1 \mathrm{ab}$ & $11.3 \pm 0.6 \mathrm{ab}$ \\
\hline \multirow[t]{3}{*}{ Naked seed } & Light & $3.3 \pm 0.4 \mathrm{c}$ & $2.0 \pm 0.0 \mathrm{~d}$ & $2.0 \pm 0.0 \mathrm{~d}$ \\
\hline & Darkness & $3.8 \pm 0.3 c$ & $2.5 \pm 0.3 d$ & $2.0 \pm 0.0 \mathrm{~d}$ \\
\hline & & \multicolumn{3}{|c|}{ PP 3} \\
\hline \multirow[t]{2}{*}{ Whole seed } & Light & $9.8 \pm 1.8 \mathrm{~b}$ & $11.7 \pm 0.7 \mathrm{a}$ & $10.3 \pm 1.0 \mathrm{ab}$ \\
\hline & Darkness & $13.8 \pm 1.8 \mathrm{a}$ & $12.3 \pm 1.3 \mathrm{a}$ & $10.5 \pm 1.2 \mathrm{ab}$ \\
\hline \multirow[t]{2}{*}{ Naked seed } & Light & $4.0 \pm 0.0 \mathrm{c}$ & $2.6 \pm 0.4 \mathrm{~d}$ & $2.0 \pm 0.0 \mathrm{e}$ \\
\hline & Darkness & $4.0 \pm 0.0 \mathrm{c}$ & $2.0 \pm 0.0 \mathrm{e}$ & $2.0 \pm 0.0 \mathrm{e}$ \\
\hline
\end{tabular}

'Means with the same letters within a seed collection were not significantly different at $P \leq 0.05$.

field stratification, the environmental conditions during the winter are not suitable for germination to occur. Seeds retrieved in March 1998 after the warm February had lower germination and viability than the February and April retrievals. It is possible that seed damage may have occurred during retrieval because seeds were often covered by an ice sheet.

Even though maximum germination percentage can be achieved after 1 to 2 months of field stratification, the benefit of prolonged stratification on these seeds can be seen from the continuous increase in germination rate (Figs. 1-4). The germination rate, as measured by the GRI, was more than $200 \%$ higher for seeds stratified in the field for several months than for those without stratification. The results from a laboratory experiment by Edwards and El-Kassaby (1995) also indicate that extended stratification improved the germination rate of Douglas fir but not its germination percentage.

Seeds of Douglas fir and ponderosa pine are readily germinable in the spring after the overwinter stratification. They may germinate given suitable temperature and moisture conditions, or lose viability rapidly by the end of the following growing season $(<20 \%$, data not shown), indicating that most seeds remain viable in the soil for less than 1 year. This is consistent with the fact that the presence of conifers in the soil is very low (Frank and Safford 1970; Kramer and Johnson 1987; McGee and Feller 1993) despite the dormancy common in coniferous species (Edwards 1986). Most conifer seeds remain viable after dispersal for only a few years, and thus cannot form persistent seed banks on the forest floor (Johnson and Fryer 1996).

\section{Effect of Stratification Duration, Light, and Seed Coat Removal on Dormancy Change}

Germination percentage $(G)$ of the control was between $38 \%$ and $71 \%$ without stratification, light, or seed coat removal (Table 1). Both species are known to require prechilling and light for dormancy release (Young and Young 1992). For Douglas fir, $\mathrm{G}$ was enhanced between $14 \%$ and $23 \%$ by either light or 1 week of stratification, but did not increase further by the combination of light and stratification. For ponderosa pine seeds, $10 \%$ to $30 \%$ enhancement in $\mathrm{G}$ by either light or stratification was found. Therefore, collection or ecotype-specific variations in the requirements of stratification for dormancybreaking for the 2 species should be considered (Edwards and El-Kassaby 1995). Seed coat removal resulted in the highest G with or without light, but $G$ of naked seed decreased with increasing stratification duration. This indicates that naked seeds of ponderosa pine can readily germinate without stratification or light treatments and that the dormancy is imposed by the seed coat. A similar dormancy mechanism (tissues surrounding embryo) has been reported for Douglas fir (cited in Jarvis et al 1996) and white spruce (Picea glauca (Moench.) Voss.) (Downie and Bewley 1996). Seed viability in darkness remained unchanged among the 3 stratification durations but decreased up to $22 \%$ under light for Douglas fir (Table 2). Seed viability of ponderosa pine was reduced by stratification when incubated under light, but the reduction was only significant in 1 collection when incubated in darkness. Viability of naked seed, on the other hand, was reduced dramatically by stratification treatment when incubated both in darkness and light. The loss of viability under prolonged stratification in this experiment may be due to the presence of excessive water. Previous studies in which seeds were imbibed for 24 hours only and then drained and kept at low temperature indicate that viability can be maintained while the benefit of stratification can still be achieved (Danielson and Tanaka 1978; Edwards and El-Kassaby 1995).

Days to $50 \%$ germination (D50) was higher in the control than any other treatments (Table 3). D50 was reduced by at least 4 days, equally with light or stratification treatment in Douglas fir, and the combination of light and 3-week stratification resulted in the lowest D50. A similar trend was found in ponderosa pine, but whether light or stratification was more effective in enhancing the speed of germination varied among seed collections. In ponderosa pine, seed coat removal resulted in the shortest D50, or the most rapid germination, with or without light or stratification (or both).

\section{Conclusions}

Seeds of Douglas fir and ponderosa pine tested in this study had various degrees of initial dormancy. One to 2 months of stratification in the grassland during late autumn and early winter will release dormancy, but continuous stratification until the following May was correlated with higher germination rate. Therefore, the grassland seedbeds near the forest edge can 
provide suitable conditions to break dormancy of Douglas fir and ponderosa pine seeds, which aids establishment in grasslands. One week of stratification (imbibition at low temperature) in the laboratory was sufficient to break dormancy in the 2 species and a similar effect can be achieved by exposure to light. Seed coat removal for ponderosa pine produced similar results, indicating that dormancy is imposed by the seed coat. Management aiming to control tree encroachment to adjacent grasslands should take the interaction between tree seeds and grassland seedbed conditions into consideration, and the control should be focused on the elimination of seeds and seedlings but not on the germination stage.

\section{Acknowledgments}

We thank Barb Brooke, Sheryl Wurtz, and Christine Kelly for assistance in data collection.

\section{Literature Cited}

Arno, S. F., and G. E. Gruell. 1986. Douglas-fir encroachment into mountain grasslands in southwestern Montana. Journal of Range Management 39: 272-276.

BAl, Y., D. T. Booth, AND J. T. Romo. 1998. Winterfat (Eurotia lanata (Pursh) Moq.) seedbed ecology: low temperature exotherms and cold hardiness in hydrated seeds as influenced by imbibition temperature. Annals of Botany 81:595-602.

Bal, Y., K. Broersma, And D. Thompson. 2000. Germination and early establishment of Douglas-fir and ponderosa pine in relation to grassland seedbed conditions. Journal of Range Management 53:511-517.

Bal, Y., K. Broersma, D. Thompson, And T. J. Ross. 2004. Landscape-level dynamics of grassland-forest transitions in British Columbia. Journal of Range Management 57:66-75.

BewLEY, J.D. AND M. BLACK. 1994. Seeds. Physiology of development and germination. 2nd ed. New York, NY: Plenum Press. 445 p.
Burkhardt, J. W., and E. D. Tisdale. 1976. Causes of juniper invasion in southwestern Idaho. Ecology 57:472-484.

Danielson, H. R., and Y. Tanaka. 1978. Drying and storing stratified ponderosa pine and Douglas-fir seeds. Forest Science 24:11-16.

Downie, B., and J. D. Bewley. 1996. Dormancy in white spruce (Picea glauca [Moench.] Voss.) seeds is imposed by tissues surrounding the embryo. Seed Science Research 6:9-15.

EdwARDS, D. G. W. 1986. Special chilling techniques for tree seeds. Journal of Seed Technology 10:151-171.

EdWARDS, D. G. W., and Y. A. EL-KassaBY. 1995. Douglas-fir genotypic response to seed stratification. Seed Science and Technology 23:771-778.

EvetTS, L. L., AND O. C. Burnside. 1972. Germination and seedling development of common milkweed and other species. Weed Science 20:371-378.

Frank, R. M., and L. O. Safford. 1970. Lack of viable seeds in the forest floor after clearcutting. Journal of Forestry 75:776-778.

HARPER, J. 1977. Population biology of plants. New York, NY: Academic Press. 892 p.

Jarvis, S. B., M. A. TaYlor, M. R. Macleod, and H. V. Davis. 1996. Cloning and characterization of the CDNA of three genes that are differentially expressed during dormancy breakage in the seeds of Douglas fir (Pseudotsuga menziesii). Journal of Plant Physiology 147:559-566.

Johnson, E. A., And G. I. Fryer. 1996. Why Engelmann spruce does not have a persistent seed bank. Canadian Journal of Botany 26:872-878.

Jones, S. K., AND P. G. Gosuing. 1994. 'Target moisture content' prechill overcomes the dormancy of temperate conifer seeds. New Forests 8:309-321.

Kramer, N. B., and F. D. JoHnson. 1987. Mature forest seed banks of three habitat types in central Idaho. Canadian Journal of Botany 65:1961-1966.

Mast, J. N., T. T. Veblen, and Y. B. Linhart. 1998. Disturbance and climatic influences on age structure of ponderosa pine at the pine-grassland ecotone, Colorado Front Range. Journal of Biogeography 25:743-755.

McGee, A., and M. C. Feller. 1993. Seed banks of forested and disturbed soils in southwestern British Columbia. Canadian Journal of Botany 71:15741583.

SAS InSTITUTE. 1995. SAS user's guide: Statistics. Cary, NC: SAS Institute.

WHITE, A. S. 1985. Resettlement regeneration patterns in a southwestern ponderosa pine stand. Ecology 66:589-594.

Young, J. A., AND C. G. Young. 1992. Seeds of woody plants in North America. Portland, OR: Dioscorides Press. 407 p. 